\title{
Bivalves from the white chalk (Maastrichtian) of Denmark, III: Cuspidariidae
}

\author{
CLAUS HEINBERG
}

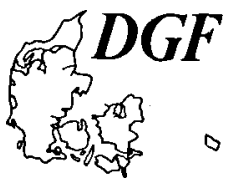

\author{
Heinberg, C.: Bivalves from the white chalk (Maastrichtian) of Denmark, III: Cuspidariidae. Bull. geol. \\ Soc. Denmark, vol. 28, pp. 39-45. Copenhagen. October 23rd, 1979. \\ https://doi.org/10.37570/bgsd-1979-28-07 \\ Seven species of Cuspidaria (Bivalvia) are described from the hardground at the summit of the \\ white chalk. Six of these are new, while one species probably has been described previously. \\ Claus Heinberg, Institut for historisk Geologi og Palaontologi, Øster Voldgade 10, DK-1350 København \\ K, Denmark. May 3th, 1979.
}

This paper continues the series of systematic descriptions of aragonitic bivalves from the Upper Maastrichtian of Denmark (Heinberg 1976, and 1978). Methodology, description of localities and information on general stratigraphy and lithology may be found in Heinberg (1976).

\section{Systematic descriptions}

All types and figured specimens are in the collection of the Geological Museum of the University of Copenhagen (numbers with MGUH).

Family: Cuspidariidae Dall, 1886

Genus: Cuspidaria Nardo, 1840

Type species: $C$. typus (= Tellina cuspidata Olivi, 1792)

\section{Cupidaria (C.) caudata? (Nilsson, 1827)}

\section{Fig. 1}

Described specimens: MGUH 14420, 14421, 14422.

Locality: Stevns Klint, immediately north of Eskesti chalk pit.

Stratum: The top hardground in the Upper Maastrichtian white chalk.

Additional material: 7 specimens, comprising 2 from north of Eskesti chalk pit, 3 from north of Kulsti, 1 from Rødvig and 1 from elsewhere on the cliff.

Diagnosis (emended): A Cuspidaria with long slender rostrum, commarginal lamellae, sharp ridges extending from umbo posteriorly on rostrum, irregular dorsoventral ribbing on rostrum, posterior lateral tooth in right valve, triangular posterior adductor scar deeply inserted.

Description: The shell is rather long relative to height. The inflated shell body has a subcircular to subtriangular outline. The distinct rostrum is rather long and slender, set off from the shell body by a rather deep ventral sulcus in the shell margin. The dorsal margin of the rostrum is concave, the ventral convex. The umbo is slightly prosogyrous.

The shell seems to be inequivalve, the left valve being the smaller. The outer surface is heavily ornamented with thin commarginal, widely spaced lamellae. On the rostrum this ornamentation is cut by two sharp ridges, extending from below the umbo to the posteroventral and posterodorsal corner of the rostrum respectively. The triangular area between these ridges is dominated by irregular dorsoventrally oriented riblets which do not form continuations of the commarginal lamellae.

The hinge area of the right valve is characterized by a long tooth-like lamellae extending from below the umbo to above the centre of the posterior adductor scar. Anterior to this lateral tooth there seems to be a thickening of the shell margin reminiscent of a cardinal tooth, probably associated with an indistinct resilifer.

The posterior adductor scar is triangular in outline, and deeply inserted in the shell, escpecially anteriorly.

Maximal dimensions: Height: $11 \mathrm{~mm}$, length: $17,5 \mathrm{~mm}$. 


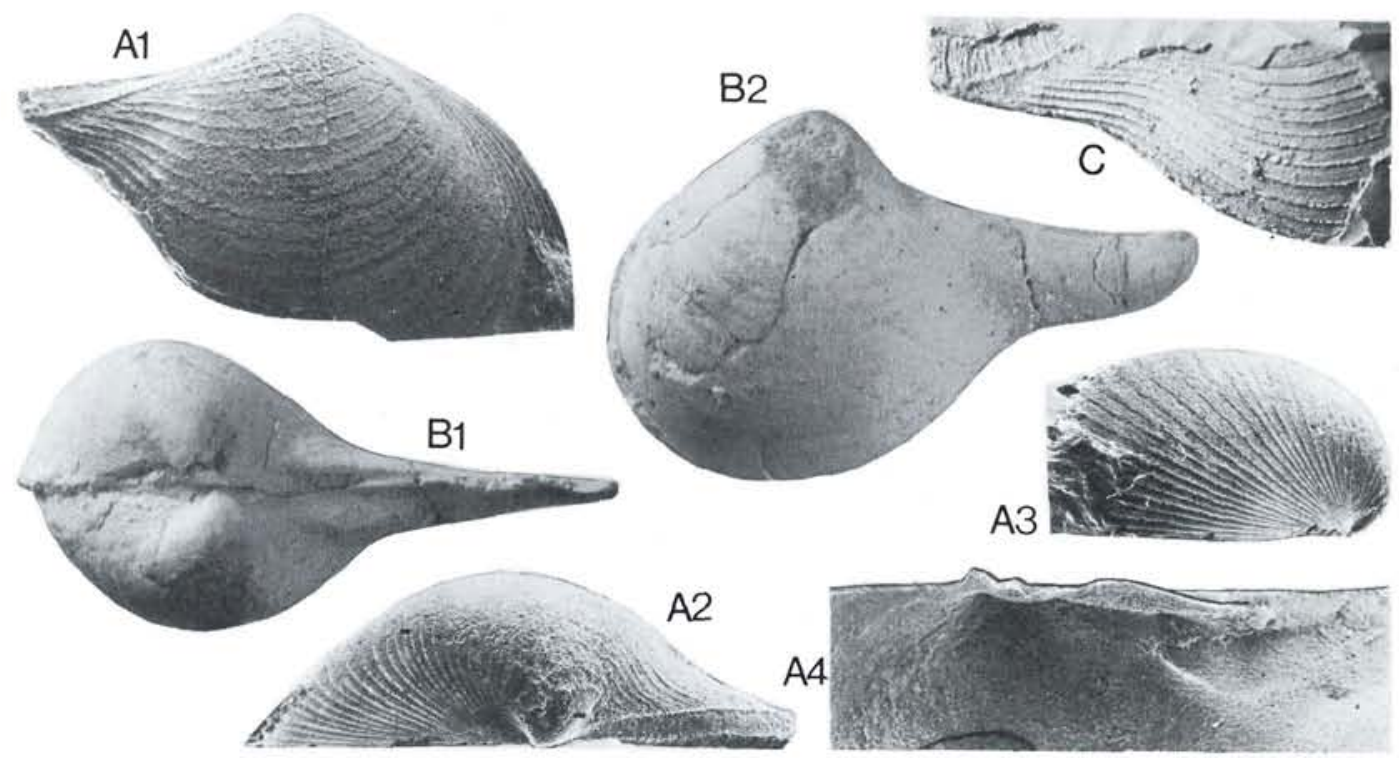

Fig. 1. Cuspidaria (C.) caudata? (Nilsson). A1, A2, A3,: Outside of a right valve seen in lateral, dorsal and anterior view. Latex cast of MGUH 14420. x8. A4: Indside of umbonal region of a right valve in ventral view. Note dentition and adductor scar. $x 11 . B 1, B 2$ : Steinkern of bivalved specimen, MGUH 14421.x3. C: Outer surface of a right valve showing ornamentation of rostrum. Latex cast of MGUH 14422, x6.

Discussion: The specimens from Stevns Klint show rather close resemblance to a number of older descriptions, all referring to Nilsson (1827) (Reuss (1845-46): Corbula caudata; Hennig (1897): Cuspidaria caudata; Müller (1898): Neaera caudata; Ravn (1902): Neaera caudata). However, as long as the types have not been in- spected the reality of these synonymies remains open. In accordance with Ravn (1902) the species is thus referred to $C$. caudata Nilsson.

Cuspidaria (C.) johannae n.sp.

Fig. 2

Holotype: MGUH 14424.

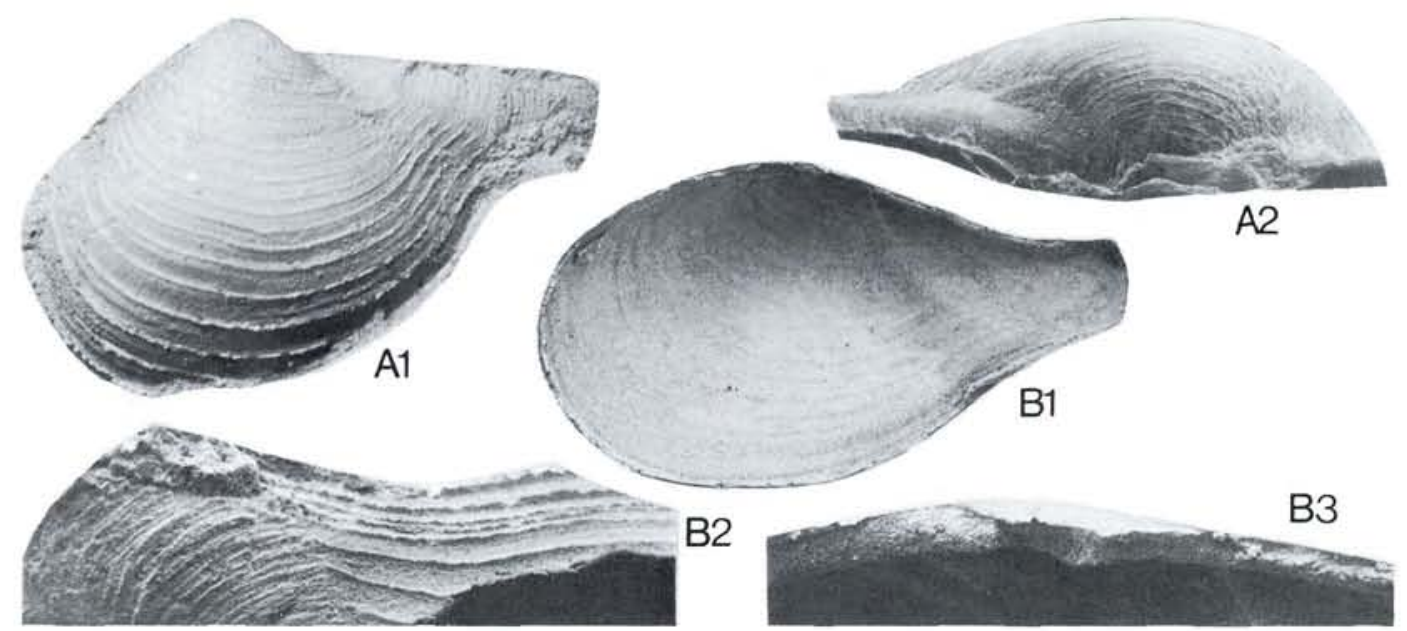

Fig. 2. Cuspidaria (C.) johannae n.sp. A1, A2,: Outside of left valve seen in lateral and dorsal view. Latex cast of MGUH $14423 . x 8$. B1: Inner surface of a left valve. Latex cast of MGUH 14424. x6. B2: Sculpture of rostrum. x15. B3: Shell margin seen from the inside, showing resilifer. $x 25$. 


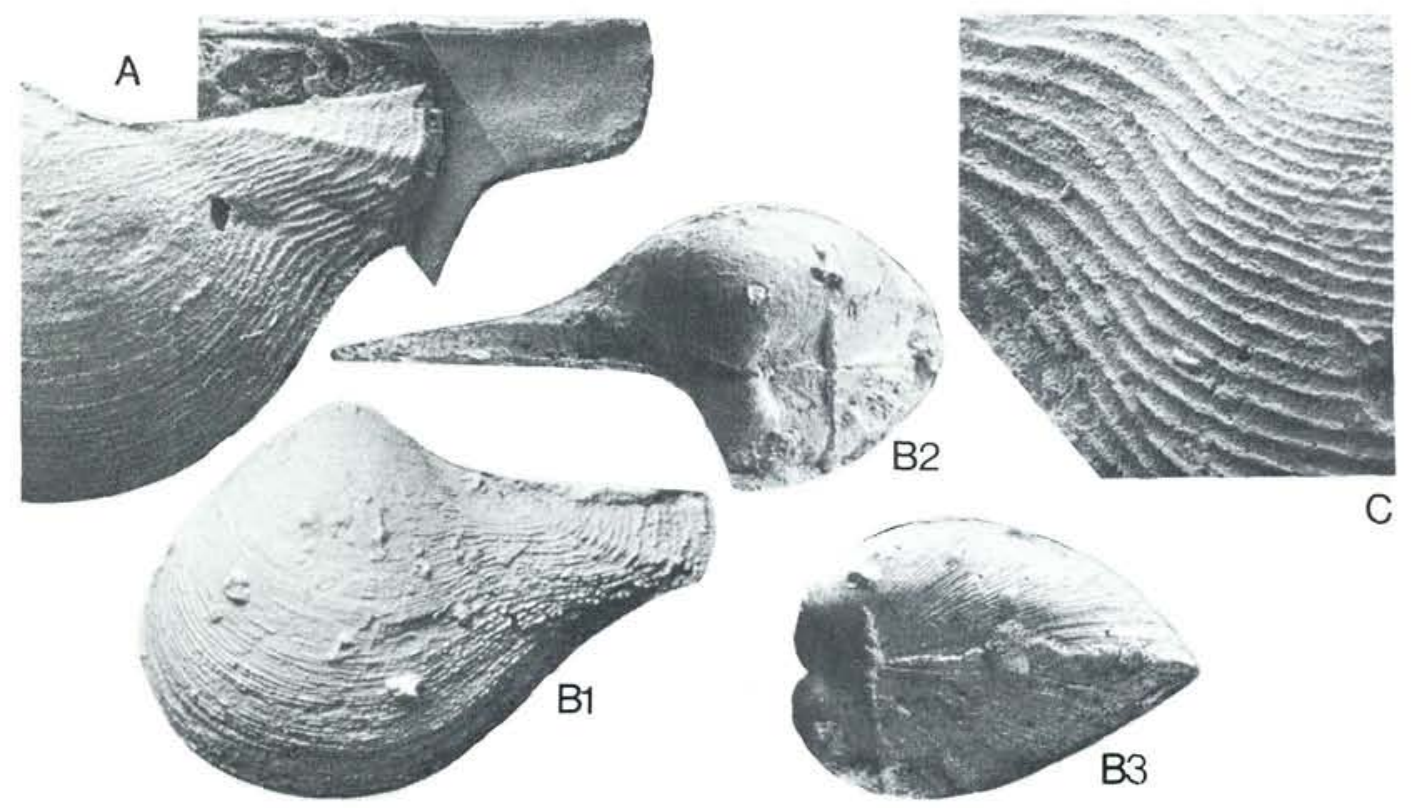

Fig. 3. Cuspidaria (C.) bentzonii n.sp. A: Outside of a left valve and indside of corresponding right valve seen in lateral view. Latex cast of MGUH 14425, x16. B1, B2, B3: Outside of bivalve specimen in lateral, dorsal and anterior view. Latex cast of MGUH $14426 . x 9$. C: Detail of ornamentation at base of rostrum. Latex cast of MGUH 14427. x28.

Type locality: Stevns Klint

Type stratum: The top hardground in the Upper Maastrichtian white chalk.

Additional material: 10 specimens, comprising 5 from north of Kulsti, 2 from north of Holtug chalk pit, 2 from north of Eskesti chalk pit and 1 from Rødvig.

Diagnosis: A Cuspidaria with ornamentation of commarginal, spaced lamellae, changing in ornamentation on the rostrum into fine striations, no radiating ribs on rostrum, rostrum short relative to shell body, elongate resilifer, no hinge teeth.

Description: The shell body is moderately inflated, ovate in outline. The rostrum is relatively short, having a wide base making the shift from shell body to rostrum very indistinct. The prominent umbo is orthogyrate. The outher surface is covered with thin, widely spaced commarginal lamellae. These lamellae terminate along a line extending from the posteroventral corner of the rostrum to below the umbo. Dorsal to this imagi- nary line the ornamentation consists of a dense striation with a dorsoventral orientation. The hinge area is smooth except for an elongate resilifer below the umbo. No adductor scars are visible.

Discussion: The ornamentation of this shell is close to that of $C$. caudata (?) except for the rostrum, which carries radiating ribs in the latter. The two species also differ significantly with respect to the general shell form.

Maximum dimensions: Height: $5.7 \mathrm{~mm}$, length: $10.5 \mathrm{~mm}$.

\section{Cuspidaria (C.) bentzonii n.sp.}

Fig. 3

Holotype: MGUH 14426.

Type stratum: The top hardground in the Upper Maastrichtian white chalk.

Additional material: 10 specimens, comprising 6 from north of Holtug chalk pit, 1 from north of Kulsti and 3 from other places on the cliff. 


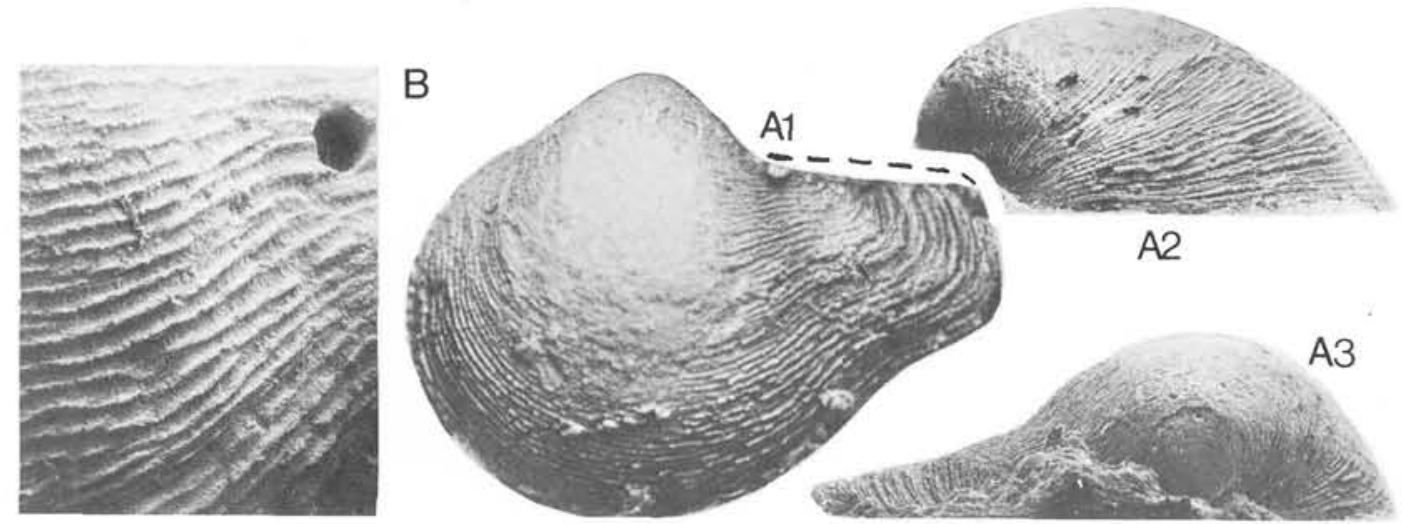

Fig. 4. Cuspidaria (C.) brittae n.sp. A1, A2, A3: Outside of left valve seen in lateral, anterior and dorsal view. Latex cast of MGUH 14428, x12, B: Detail of ornamentation at base of rostrum (with gastropod boring). Latex cast of MGUH 14429. x25.

Diagnosis: A Cuspidaria with a relatively long rostrum, rostral keel, commarginal ribbing interdigitating anteriorly and at base of rostrum. Hinge with lamellate tooth.

Description: The shell body is inflated, subcircular in outline tapering posteriorly into the relatively long rostrum. The dorsal margin of the rostrum is straight, the ventral concave. The umbo is prominent, slightly prosogyrate. The ornamentation consists of rather densely spaced commarginal ribs which interdigitate in a characteristic manner, especially anteriorly and at the transition between the shell body and the rostrum. The ribs are fine on the shell body, becoming coarser and wider posteriorly. A distinct keel, caused by a sharp bend of the shell, connects the umbo with the posteroventral corner of the rostrum. The commarginal ribs cross this keel as they turn in a dorsal direction. The hinge line is only partly known. In the right valve there is a tooth like lamella posterior to the umbo.

\section{Cuspidaria (C.) brittae n.sp.}

Fig. 4

Holotype: MGUH 14428.

Type locality: Stevns Klint, north of Holtug chalk pit.

Type stratum: The top hardground in the Upper Maastrichtian white chalk.
Additional material: 2 specimens from north of Holtug chalk pit.

Diagnosis: An inflated, relatively short Cuspidaria with a short wide rostrum, commarginal densely spaced ribs, no keel on rostrum.

Description: The shell is inflated, having a prominent subcircular body and a relatively short wide rostrum which ventrally is separated from the shell body by a sinus. The umbo is prominent, orthogyrate. The outer surface of the shell is ornamented with densely spaced commarginal ribs. The individual rib seems to vary in width along its length. The course of the rib can be slightly undulatory. On the rostrum the ribs turn in a dorsal direction through a gentle curve. No rostral keel is present. The inner surface is not known.

Maximum dimensions: Height: $3.8 \mathrm{~mm}$, length: 5 $\mathrm{mm}$.

Cuspidaria (C.) lisbethae n.sp.

Fig. 5

Holotype: MGUH 14430. Height: $3 \mathrm{~mm}$, length: $4 \mathrm{~mm}$.

Type locality: Stevns Klint at Rødvig.

Type stratum: The top hardground in the Upper Maastrichtian white chalk. 


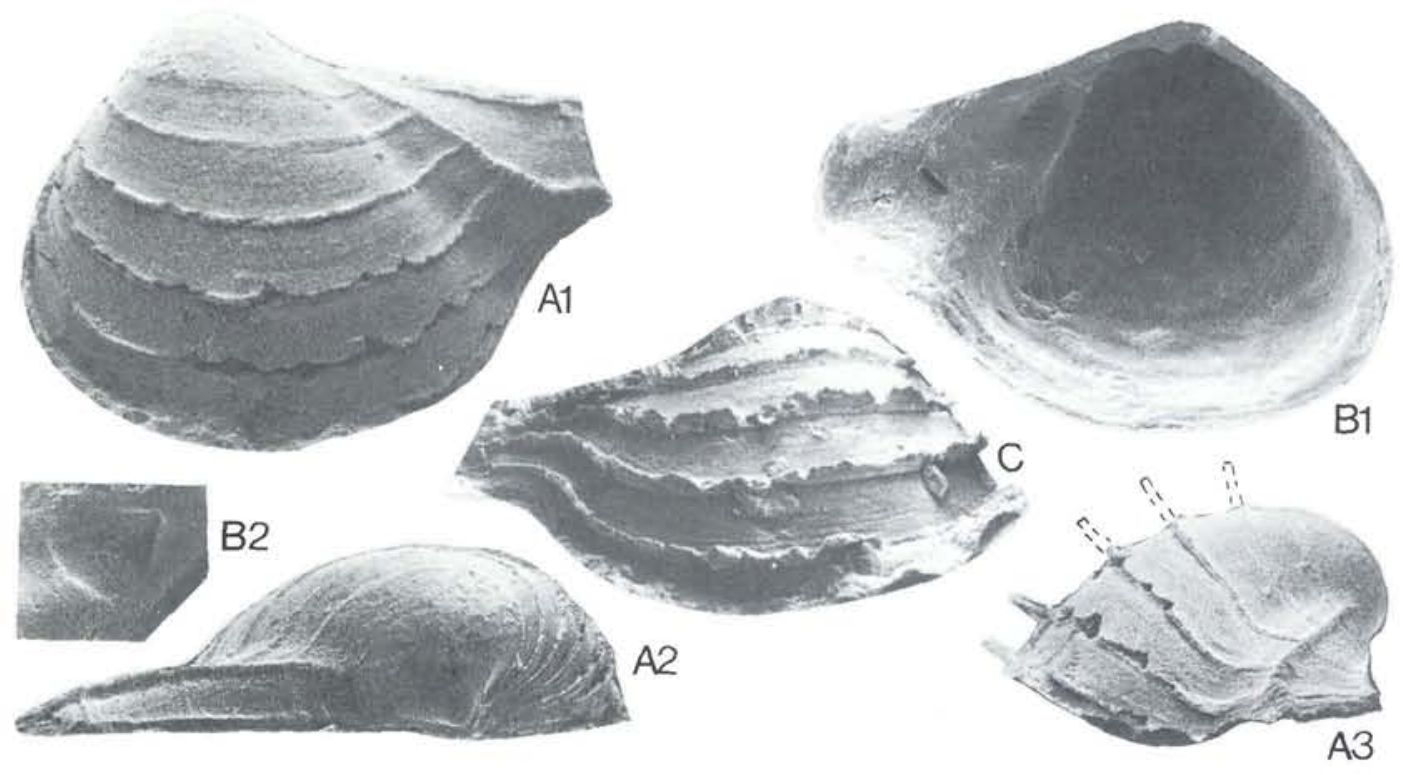

Fig. 5. Cuspidaria (C.) lisbethae n.sp. A1, A2, A3: Outside of a left valve seen in lateral, dorsal and posterior view. Latex cast of MGUH 14430. x15. B: Indside of a left valve. Latex cast of MGUH 14431. B2: Detail of B1 showing adductor scar. x12. C: Outside of a right valve in ventral view. Latex cast of MGUH 14432. x13.

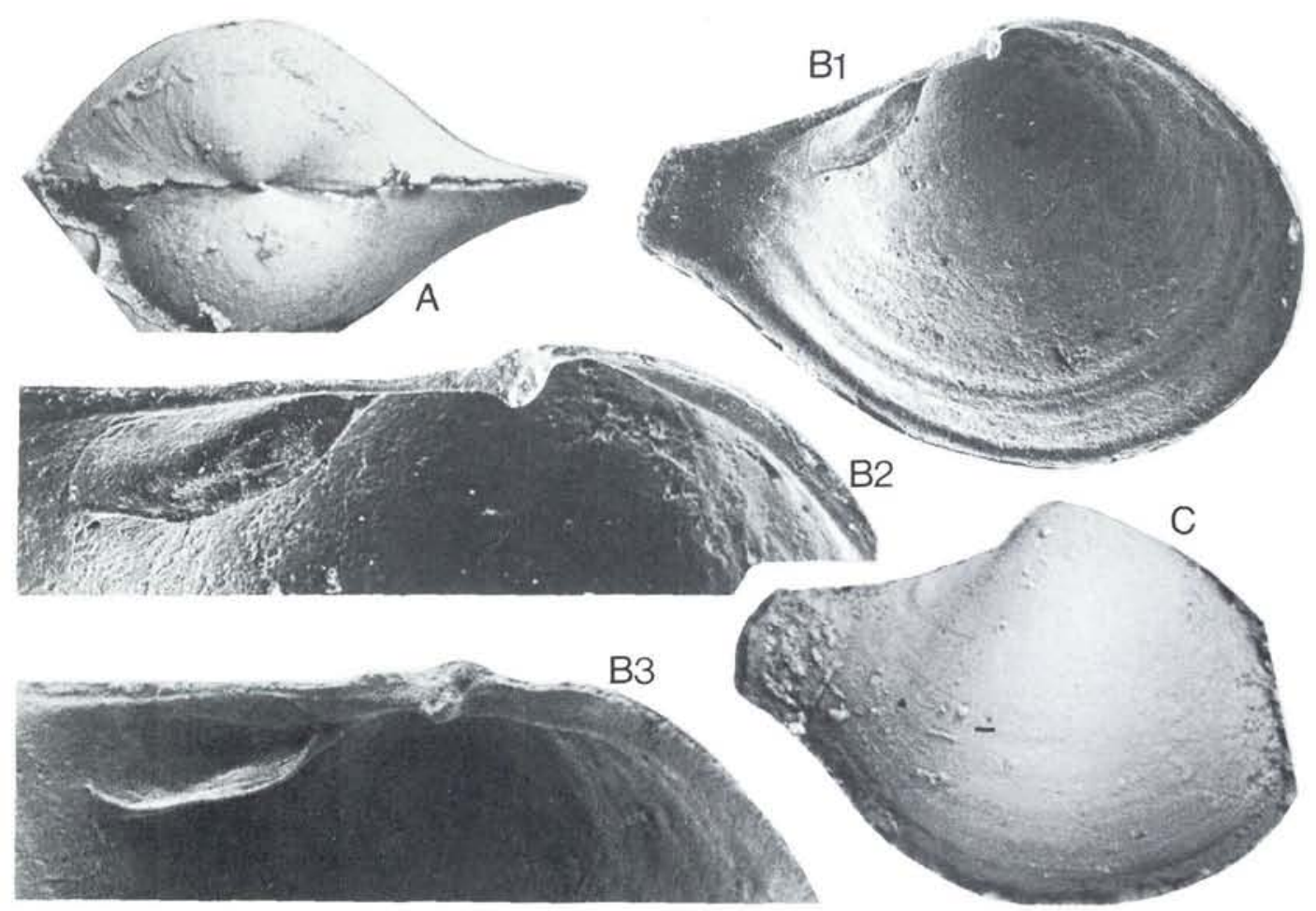

Fig. 6. Cuspidaria (Halonympha) kanae n.sp. A: Outside of bivalve specimen in dorsal view. Latex cast of MGUH 14433. x11. B1: Indside of a left valve. Latex cast of MGUH 14434.x12, B2, B3,: Detail og B1 in lateral (B2) and latero-ventral view. x25 \& 20: Outer surface of a right valve in lateral view. Latex cast of MGUH 14435. xI2. 
Additional material: 6 specimens, comprising 3 from Rødvig, 2 from north of Holtug chalk pit and 1 from north of Eskesti chalk pit.

Diagnosis: A Cuspidaria ornamented with commarginal widely spaced thick lamellae, distinct keel connecting umbonal region with posteroventral rostral corner.

Description: The inflated shell body is subcircular in outline. The rostrum is short, wide, marked off from the shell body by a ventral sinus. Dorsally the shell margin and the rostrum form a straight line. The prominent umbo is orthogyrate. The surface of the shell is ornamented with heavy commarginal lamellae. Two round-crested keels connect the umbo with the posterdorsal and the posteroventral corner of the rostrum respectively. The area between the two ridges is smooth. Ligament and possible dentition is unknown. The triangular posterior adductor scar is situated at the base of the rostrum. The scar is inserted into the shell.

Maximum dimensions: Height: $3.3 \mathrm{~mm}$, length: 5 $\mathrm{mm}$.

\section{Cuspidaria (Halonympha) kanae n.sp.}

Fig. 6

Holotype: MGUH: 14434. Height: $4 \mathrm{~mm}$, length: $5.6 \mathrm{~mm}$.

Type locality: Stevns Klint, north of Holtug chalk pit.

Type stratum: The top hardground in the Upper Maastrichtian white chalk.

Additional material: 36 specimens, comprising 15 from north of Holtug chalk pit, 13 from north of Kulsti, 5 from north of Eskesti chalk pit, 1 from Rødvig and 2 from other localities.

Diagnosis: A smooth shelled Cuspidaria with a thin platy septum extending from the inner side of the rostrum, small spoon shaped resilifer.

Description: The shell is inflated with a globular shell body and a flat, relatively short rostrum. The dorsal margin forms posteriorly a slightly concave curve from the umbo to the tip of the

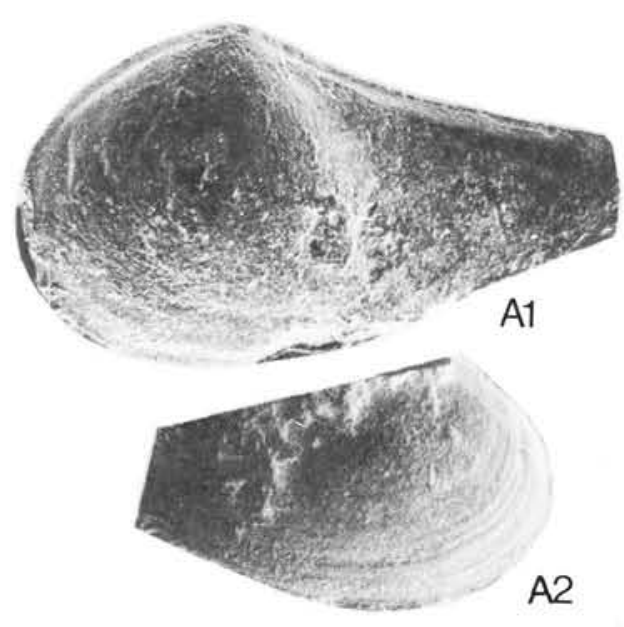

Fig. 7. Cuspidaria (Rhinolama?) sp.nov. A1, A2: Inner and outer surface of a left valve in lateral views. Latex cast of MGUH 14436. x16.

septum. The ventral margin of the rostrum is likewise slightly concave. As a whole the rostral margins curve gently into the ovate margin of the shell body. The shell is inequivalve, the right valve being the smaller, resting with its sharp margin on the commarginal shelf of the left valve. The surface of the shell is smooth except for faint growth lines. The hinge region is edentulous with a small but distinct, ventrally projecting condroghore. The inner surface of the shell is smooth, carrying a thin, platy septum below the proximal part of the rostrum. The septum is parallel to the plane of commissure. A faint line of the septum possibly marks the outline of an (adductor?) muscle.

Maximum dimensions: Height: $6 \mathrm{~mm}$, lenght: ca. $9 \mathrm{~mm}$.

\section{Cuspidaria (Rhinoclama?) sp.nov.}

\section{Fig. 7}

This species is represented only as a single, badly preserved specimen (MGUH 14436) which does not allow a proper description. The shell has an elongate ovate outline, the rostrum being a continuation of the shell body. The hinge region seems to be devoid of any distinctive structures. The outer surface is smooth. Height: $2.3 \mathrm{~mm}$, length: $4.2 \mathrm{~mm}$.

Locality: Stevns Klint, north of Holtug chalk pit. 


\section{Dansk sammendrag}

Med dette arbejde foreligger tredie del af en serie beskrivelser af aragonitskallede muslinger fra det hærdende skrivekridt ( $\emptyset$. Maastrichtian) på Stevns Klint (Heinberg 1976, 1978). Syv arter inden for slægten Cuspidaria er beskrevet. En enkelt af arterne er muligvis beskrevet tidligere, de ovrige seks er nye. I materialet indgår underslægten Halonympha som hidtil kun er kendt recent.

\section{References}

Heinberg, C., 1976: Bivalves from the white chalk (Maastrichtian) of Denmark: Limopsidae. Bull. geol. Soc. Denmark 25: $57-70$.
Heinberg, C., 1978: Bivalves from the white chalk (Maastrichtian) of Denmark, II: Arcoida. Bull. geol. Soc. Denmark 27: 105-116.

Hennig, A., 1897: Revision af Lamellibranchiaterna i Nilssons »Petrificata Suecana formationis cretaceaek. Kungl. Fysiogr. Sällskapets $i$ Lund Handlinger. Ny Följd. 8: 1-66.

Müller, G., 1898: Die Molluskenfauna des Untersenon von Braunschweig und Ilsede. I. Lamellibranchiaten und Glossophoren. Abhandl. der K. Preussischen geolog. Landesanstalt. Neue Folge, Heft 25. Berlin.

Nilsson, S., 1827: Petrificata Suecana formationis cretaceae. Lund.

Ravn, J. P. J., 1902: Molluskerne i Danmarks Kridtaflejringer I. Lamellibranchiater. Kgl. Danske Vidensk. Selskab. Skr. 6 Nat. Mat. afd. 11: 74-138.

Reuss, A. E., 1945-46: Die Versteinerungen der Böhmischen Kreideformation. Stuttgart. 